not only absolutely but also relative to the more overt forms of recreational use.

The obvious fact that it is cheaper in cost and more economical of time to transport goods rather than people will have an increasing effect on land use and land management over the next halfcentury. The management of open space lands adjacent to urban areas to provide a sense of natural experience under conditions of intensive use will be greatly expanded. Similarly, there will be intensive efforts to develop systems under which large numbers of people can live in structures interspersed through what is thought of as a natural landscape. These emerging patterns will constitute a major opportunity for foresters and other resource managers to work with landscape architects and planners in the development of total environments managed for people.

The year is 2021. Some 335 million people live in the United States and Canada. The automobile has been subjugated and serves only as one part of a developing total transportation system. A coast to coast trip still takes nearly five hours, but it is now possible to reach the airport in an efficient and sensible manner. The small boy is outside enjoying neighborhood recreational lands. His elders still think taxes are too high. Adjustment to a 30-hour work week in primary employment has led to a major sector of economic activity known as leisure work, in which the individual functions as a producer as well as a consumer. There are very great inequities and tensions among the major blocks of people throughout the world, but recognition that survival is a mutual problem has led to programs of international interactions mounted on a scale approaching that formerly reserved for war. The North American timber cut amounts to 25 billion cubic feet, with one-third of this going directly to overseas markets. Although housing generally meets minimum standards, one-third of the people need better homes to enjoy a full life. An editorial in the Forestry Journal-Chronicle comments: "Wilderness use still represents less than one per cent of outdoor recreational activity, which perhaps is one measure of our increasing effectiveness in managing the non-wilderness environment for people."

1 LEOPOLD, ALDO. 1921. The wilderness and its place in forest recreational policy. J. Forest. 19:7187-12.

${ }^{2}$ SUTTON, ROY F. 7971. Section news. Forest. Chron. 47:167.

- SPURR, STEPHEN H. 1966. Wilderness management.

Horace M. Albright Conservation Lectureship VI,

Univ. Calif. Berkeley. 17 p.

\title{
World consultation on forestry education and training
}

Some of the main points discussed at the first World Consultation on Forestry Education and Training at Stockholm, 1971, are given here by J. W. B. SISAM who was elected Chairman of the Consultation.

L'éducation de la foresterie de par le monde. Quelques-uns des principaux points discutés lors de la Première Consultation Mondiale sur l'éducation et l'entraînement propres $\grave{a}$ la foresterie et tenue d̀ Stockholm en 1971 sont exposés ci-dessous. Nous notons parmi ceux-ci: la nécessité de présenter le cas de la foresterie de telle sorte qu'il soit compris par les planificateurs, administrateurs et politiciens; la possibilité (et les fonds) de poursuivre pour le forestier son éducation tout au long de sa carrière: l'éducation Technique et professionnelle de même que l'entraînement devraient être fermement orientés; la critique des programmes inefficaces d'extension; lamélioration dans la diffusion des recherches pour ceux qui peuvent les mettre en pratique et l'inclusion de cours sur la foresterie mondiale. Un certain nombre de résolutions furent expédiées à la FAO et/ou aux gouvernements les plus concernés.

In many of the more industrialized forest countries of the world where forestry, in common with most other sectors, has been strongly influenced in recent years by the impact of science and technology and the changing requirements of society, there has been increasing concern as to the adequacy of traditional forestry education and training programs to qualify professional, technical and vocational staff to meet the challenges ahead. Such concern has been expressed by the widespread reorganization of curricula, adjustments in the scope and emphasis of degree and diploma courses and the upgrading of vocational courses, the initiation of comprehensive surveys of forestry education programs and responsibilities, and the convening of regional or national conferences.

Somewhat different, though quite as serious and certainly more fundamental are the difficulties to be found in this general field in the less indus- trialized countries - the developing countries of the world. In many cases the problem here is to create a meaningful program and maintain high academic standards when there is no tradition of indigenous forestry education, no local teaching staff, no textbooks relevant to the local situation, a public unaware of the need for trained forestry personnel, and limited resources to devote to forestry education. Within the means available decisions must be made as to the emphasis that should be given to professional, technical and vocational programs, and what provision, if any, can be made for public education and extension.

A proposal for a world-wide conference to be concerned solely with the study of problems relating to forestry education and training was made by the FAO Advisory Committee on Forestry Education at a meeting in Venezuela in 1963 . Subsequently this suggestion received the support of the European Forestry Commission, the North American Forestry Commission, and the FAO Technical Committee on Forestry and Forest Products. The first World Consultation on Forestry Education and Training became a reality when the Government of Sweden extended an invitation for it to be held in Stockholm during the period September 28 to October 7, 1971. The program $^{1}$ was sponsored and developed by FAO in close collaboration with UNESCO and ILO. In Stockholm the organization and overall supervision of the meetings were the joint responsibility of FAO and

${ }^{1}$ Background papers are listed at the end. 
the Swedish International Development Authority (SIDA) on behalf of the host country. There were in attendance some 300 participants from 75 countries and certain international agencies that are involved either technically or financially with plans and programs to assist developing countries.

Recognizing that the forester's basic responsibilty is to maximize the benefits of the forests for mankind, the Consultation considered two major variations of this theme as background for discussion; first that forests, being a vital part of man's environment, may be used and managed primarily in terms of Environmental Forestry, and second that where wood represents a key material resource the emphasis in management will be on Production Forestry. As pressure on forests and related resources increases in terms both of environment values and industrial growth the need to understand and apply the concept of multiple or integrated use will become increasingly urgent. The resulting variegated pattern of management will almost certainly involve specialists from a number of related disciplines and the value of the team approach must be recognized. Nevertheless in many instances the forest land manager's position will become more demanding upon the individual as a planner and decision-maker with responsibility for evaluating tradeoffs between industrial use and environmental control. Here also the professional forester has a special responsibility for the long-term public interest which may well be out of step with shortterm values that often strongly influence economic decisions; however, such responsibility does not imply a static approach to management but rather qualified adaptability as the speed of social and technological change accelerates.

\section{Professional education}

Discussion emphasized the essentiality of high quality in all programs at university level; also in view of the broadening scope of forestry and the diversity of problems involved, there was strong support for a multi-discipline approach with sufficient flexibility to serve the future needs of the profession and the interests of the students.

It was generally agreed that professional forestry education should be organized in association with broadly-based universities rather than as independent schools. To take full advantage of the university environment and to justify periodic time-consuming revisions of curricula, the objectives of the program should be precisely defined and periodically reviewed with an evaluation of achievements to date.

While the Consultation showed no unanimity on the question of undergraduate specialization, one of the key papers outlined three main routes by which forestry education could be directed to produce a/ forest managers, b/ environmental specialists, or c/ a combination of policy-maker and specialized, practical technician. In essence these might serve the needs respectively of production forestry, environmental forestry, or the beginning of formal forestry education in a developing country or region.
From a global viewpoint forestry education might be regarded as a dynamic continuum embracing all three approaches, varying in emphasis from time to time and place to place in relation to local conditions and the changing role of forestry.

There was wide agreement that every effort be made to improve the position of forestry students within the university and the image of the profession both within and outside the university. Steps suggested to this end included the greater involve,ment of students in general university affairs; the involvement of non-forestry staff and other departments in forestry courses; the encouragement of non-forestry students to take forestry units; and a broadening of the activities of university forestry departments, for example in public education and extension, in continuing education and in research. It was agreed that if foresters are to compete successfully with other sectional interests for financial support for education, research and overall development, they must present their case in terms clearly understood by planners, administrators and politicians.

There was general support for the view that, within the context of production forestry, education and training for the wood-using industries and marketing are as important as for timber growing and forest land management. To serve the needs of developing countries the facilities for wood utilization programs could probably best be provided through an established department of forestry in a broadly-based university. In view of the limiting factors of cost and scarcity of qualified staff, these might, at least in the first instance, be developed as regional centres to serve a number of countries with similar requirements.

Opportunities for continuing education throughout the forester's career is essential if a high level of professional competence is to be maintained, and should be planned for each individual at intervals of not more than 5-10 years. In this connection the Consultation recommended that the appropriate national and international agencies provide fellowships for, and facilitate participation in specially arranged short-term courses and study tours and take such other action as to ensure an effective program in continuing education.

\section{Technical and vocational education and training}

As the forest technician is often the one directly responsible for the quality of work performed in the field, his qualifications for the job, both personal (through selection) and technical (through training and experience) are of vital importance.

The Consultation agreed that programs of education and training at this level should be designed and conducted with reference to the socio-economic and forestry environments they are intended to serve, and should be goal-oriented and directed toward realistic objectives within a particular environment. At the same time provision must be made for the general education of the individual when his basic schooling is insufficient. Ideally there should 
be a pattern of education and training carefully integrated with career development and capable of response to industrial or technical change. In the same way programs of vocational education and training should aim at promoting both the forest worker's welfare and his productivity.

Academic requirements for admission to courses for forest technicians must be realistic in terms of the education level prevailing in the region or country in question. As a general rule, entering students should have had some previous forestry work experience and be reasonably mature - usually not less than 20 years of age. Also, work experience is an important prerequisite for admission to a vocational training program; where such experience is being provided for people interested in entering the work force, it must be at a safe level and within the individual's capabilities.

While instruction in safe working practices is an essential part of all training programs, there is a most urgent need for greater attention being given to this in developing countries. Also in these countries workers and employers alike would benefit from training in better in-plant housekeeping and improved working techniques with existing or moderately improved equipment.

\section{Public relations and extension}

The Consultation was highly critical of the generally ineffective extension programs in forestry, in contrast, for example, with those in agriculture, resulting in very poor communication on behalf of professional forestry with the public and their elected representatives in government. As a result the practice of forestry has often tended to develop in isolation, outside the main stream of man's interests and activities, with the public generally having little knowledge or understanding of its objectives and function; and as the pressure on forest lands increases and becomes more diversified there tends to be some confusion as to the role the forester is intended to play in the overall approach to management.

Out of this there developed a general agreement that the public image of forestry must be improved and to this end sustained public relations programs are essential. As these must often be the responsibility of professional foresters, and the subject of expert knowledge and a systematic approach rather than intuitive, it was recommended that forestry schools consider the introduction of courses in communication and public relations.

Another area in which forestry appeared to be relatively inefficient and where improvement was urgently needed, was in the communication of relevant research information to those who could put it into practice.

\section{Requirements in developing countries}

In considering specifically the problems affecting forestry education and training in the less industrialized countries it was agreed that there was need for better understanding of the problems involved and to assist in their solution more international cooperation, especially between forestry educational institutions; as background for this there should be a detailed study of the past and present role of all multi- and bi-lateral agencies in forestry education. It was further suggested that in helping to provide forestry educational facilities for developing countries FAO should make greater use of established universities and that university forestry schools should be better prepared to meet this need.

It was agreed that a short introductory course on world forestry should be included in all undergraduate forestry curricula; this would help students to understand something of the growing interdependence within the world forest and timber economy, and the socio-economic contexts within which forest resource problems have to be resolved in different parts of the world.

\section{Potential demand for trained personnel}

In order to provide background for the Consultation a world-wide survey of forestry education and training was undertaken. In this connection an effort was made, through the use of a newly developed methodology, to determine for the developing regions a quantitative estimate of trained manpower requirements for the future. Such an appraisal is of course of vital importance as the basis for determining the staff, facilities and financial support that will be needed. To illustrate briefly from the results of one survey, it is estimated that to meet the 1985 requirements for Latin America, the 1969 total of professional foresters (approx. 1500) would have to be expanded to some 6500 , while at the technical level, the present overall total of about 2500 trained personnel should be increased to 31,000 . These targets would require the establishment of some new schools but perhaps more important the updating and expansion to full capacity of existing schools.

While little has been done formally to project the future demand for qualified forestry personnel in the more industrialized countries, there are indications that at least in some regions the supply may tend to exceed the demand, partly because of the rapid expansion of post-secondary education and training programs in general, and partly because of the technological advances in many areas affecting forestry activity. Does this mean that there should be a sharp restriction on the intake of candidates for forestry programs? Not necessarily, at least in the view of the author of one of the background papers: in discussing this matter he raised the question as to whether we might not "broaden our concepts and provide also a range of options that will render the forestry school clearly superior to the liberal arts school as a preparation for responsible citizenship and a richer life". And a participant from the United States pointed out that even now a large proportion of the 18,000 students registered in forestry schools in that country do not intend to practice forestry but find the university work in this field to be an interesting and rewarding means for obtaining a general education.

June 1972 The Forestry Chronicle 


\section{Recommendations}

The majority of recommendations adopted by the Consultation were aimed at improving conditions and opportunities for forestry education and training in developing countries. These were addressed to FAO and/or the governments most directly concerned. In addition to these and the recommendations already mentioned, the Consultation adopted resolutions on a number of matters of general interest:

- That, in view of the widespread activity in curriculum revision, FAO encourage the exchange of information between forestry education centres in different countries as to the principles and procedures that are being followed and also with reference to innovations being made to adapt education and training to forestry's changing needs.

- That, because of the great significance of close cooperation now and in the future, surveys be made of all existing arrangements for international cooperation in forestry training, and of educational and associated research exchanges taking place under bi-lateral arrangements in the forestry and forest products sectors. A preliminary survey along these lines is being undertaken by the Institute for International Forest Resources of the University of Wisconsin.

- That, as the development and practice of forestry will be strongly influenced by the socio-economic environment of the individual country or region, forestry education and training programs at all levels include relevant social and economic subjects.

- That, in view of the findings of the Consultation in terms both of problems and prospects, FAO a/ continue to give priority to its work in forestry and forest industries education, b/ expand and strengthen the activities of its Advisory Committee on Forestry Education, and c/ take steps to organize a second World Consultation on Forestry Education and Training, perhaps about half-way through the second UN Development Decade.

\section{PAPERS PRESENTED AT THE CONSULTATION}

\section{Plenary: Background Papers}

FAO/UNESCO/ILO World Conference on Agricultural Education and Training. FAO Secretariat, Rome. / The forester's role in the face of social and economic change. Stephen $\mathrm{H}$. Spurr and R. Keith Arnold, United States. / Foresters of tomorrow. Hernán Cortés Salas, Chile. / The advances in science and technology as they affect education and research in forestry and forest products. Walter Liese, Federal Republic of Germany. / Forestry education: to whom and for what? Jack C. Westoby, FAO, Rome. / Present and future trends in forestry education systems. Marion Coulon,
Belgium. / The students' views on forestry education. L. G. Bell, United States; Ch. Dorel, Romania; R. Gaete Puelma, Chile; M. S. Ibianga, Nigeria; C. Pouilloux, France; R. L. Singh, India. / Information of the public in relation to forestry development. S. A. Hejmadi, India. / Some implications of communication research. Karl-Erik Wärneryd, Sweden. / Strengthening international cooperation in education for forestry and forest industries. Charles C. Larson, United States. / External aid for forestry education. M. L. S. B. Rukuba, Uganda.

Plenary: Regional Reviews of Forestry Education and Training

Forestry education and training in Latin America. Hardy L. Shirley, United States, and J. Prats Llauradó, FAO, Rome. / Forestry education and training in Africa. Haluk A. Hilmi, FAO, Rome. (Based on report by André M. Lafond, Canada). / Forestry and forest industrial education and training in the developing countries of the Asia-Pacific region. S. D. Richardson, United Kingdom. / Forestry education and training in the Near East. M. Said Kettaneh, Iraq. / Forestry education in some European countries including Israel and Turkey. G. Speidel, Federal Republic of Germany. / Present situation and trends in forestry education and training in Eastern Europe. I. Damian, Romania. / Forestry education and training in North America. J. S. Bethel, United States, and J. W. B. Sisam, Canada. / Forestry education in Australia, Japan and New Zealand. J. D. Ovington, Australia.

\section{Commission I: Professional Education}

The goals of university level forestry education: its scope and its place in the general educational system. Louis Velay, France. / Methodological problems related to curriculum revision - the Swedish experience. Nils-Erik Nilsson, Sweden. / Ecological aspects of forestry education. Gerardo Budowski, IUCNNR, Geneva. / The content of professional forestry education with special reference to production forestry. F. Jörgensen, Uganda. / Curriculum problems in wood science and forest products - university level. Fred E. Dickinson, United States; and A post-graduate course in timber technology and management for developing countries. S. D. Richardson, United Kingdom. / The quality of forestry education: innovation in attitudes, organization and methods. J. L. Harley, United Kingdom. / Continuing education in forestry. John M. Yavorsky and Austin F. Hamer, United States. / Evaluation of training. A. Jerkedal, Sweden.

Commission II: Technical and Vocational Education and Training

College of African Wildlife Management, Mweka, Tanzania. A. J. Mence, Tanzania. / Intermediate level forestry training programmes. Jean-Claude Waller, France. / Content of technical level forestry training: Temperate Regions. Hans-Henrik Isene, Norway. / Content of technical level forestry training: Semi-Arid Regions. A. Polycarpou, Cyprus. / Technical level forestry education and training in Tanzania. C. S. Mmbando, Tanzania. / The content of technical level training for forest industries: Sawmills. Lasse Hellman, Finland. / The quality of non-university level forestry training. Eric Falk, Sweden. / Vocational training for forestry. B. Strehlke, ILO, Geneva. / A review of worker-level training for the sawmill industry in Sweden. Carl-Johan Lundberg, Sweden. / The efficiency of intermediate level forestry education. Rémy Delphin, FAO, Rome. 